\title{
Schumpeterian Entrepreneurship
}

\author{
Serguey Braguinsky, Carnegie Mellon University * \\ Steven Klepper, Carnegie Mellon University ${ }^{* *}$ \\ Atsushi Ohyama, University of Illinois, Urbana-Champaign ${ }^{\star \star *}$
}

\begin{abstract}
Based on recent findings concerning the best performing startups, we develop a model of Schumpeterian entrepreneurship in which founders exploit ideas they learned through their employment. The model yields distinctive implications about how labor market experience and earnings at work influence the probability of a worker becoming an entrepreneur, earnings as an entrepreneur relative to paid work, and persistence in entrepreneurship. These implications are tested using data on the earnings of scientists and engineers, which are common founders of high growth startups. The sample is pared down to those that worked in and founded businesses related to their education in order to isolate the best candidates for Schumpeterian entrepreneurship.

JEL classification: M13, J31
\end{abstract}

Date of this version: November 2008

Print date: 14 February, 2009

\footnotetext{
* Department of Social and Decision Sciences, Pittsburgh, PA 15213, email address: sbrag@andrew.cmu.edu ** Department of Social and Decision Sciences, Pittsburgh, PA 15213, email address: sk3f@andrew.cmu.edu.

*** Institute for Genomic Biology, Urbana, IL 61801, email address: atoyama@igb.uiuc.edu
}

Acknowledgements: Braguinsky and Ohyama gratefully acknowledge support from the Kauffman Foundation. The use of NSF data does not imply NSF endorsement of the research methods or conclusions contained in the paper. 


\section{Introduction}

Numerous visions have been articulated about the role of the entrepreneur in a capitalist economy. Perhaps the best known is Joseph Schumpeter's view of the entrepreneur in the Theory of Economic Development. Schumpeter's entrepreneur is an agent of change that is the source of his famous creative destruction. He introduces a new good or a new method of production, opens a new market or discovers a new source of supply, or carries out a new organization of an industry. He upsets the conventional way of doing things. When successful, he elicits widespread imitation. Such success "presupposes a great surplus force over the everyday demand and is something peculiar and by its nature rare" (Schumpeter [1949]).

What is the impetus for this kind of Schumpeterian entrepreneurship? Popular theories of entrepreneurship feature the role of risk taking (Kihlstrom and Laffont [1979]), managerial ability (Lucas [1978]), wealth (Evans and Jovanovic [1989]), and

preferences for the control, flexibility and other job attributes that come with being one's own boss (Hamilton [2000]) as the primary motivations for entrepreneurship. While all receive support from empirical investigations of the self employed and business owners, none maps into entrepreneurship with the singular impact envisioned by Schumpeter. Studies of the most successful business startups suggest they are quite different from the typical new business. They tend to be founded by well educated individuals based on ideas they encountered through their prior employment (Bhide [2000], Kaplan et al. [2009], Klepper and Thompson [2009]). While there is considerable churn in the early management of such enterprises, once solidified their strategies tend to live on (Kaplan et al. [2009]). Consistent with Schumpeter's vision, they seem to be more about ideas and less about people, with the ideas originating from work experience.

We develop a model of such entrepreneurship in order to derive various testable implications that can be used to probe its importance and functioning. In the model, employees of incumbent organizations are assumed to continually receive ideas of unknown value that they could develop in their own firms. The value of developing an idea depends upon the general talent of the employee, with talent also conditioning the employee's earnings at paid work but yielding a greater payoff when combined with a 
valuable idea. The average idea is not worth pursuing, and at first employees cannot differentiate the value of ideas and so no ideas are developed. As they gain labor market experience, employees become better able to judge ideas, and firms are disproportionately started by high wage workers to develop ideas with the best prospects. Entrepreneurs learn from experience about the value of their ideas and return to paid work when the expected value of continuing to pursue the ideas is less than the wage from work.

The model yields distinctive implications about how labor market experience and earnings at work influence the probability of a worker becoming an entrepreneur, earnings as an entrepreneur relative to paid work, and persistence in entrepreneurship. We test the model using data on the employment and earnings of scientists and engineers, which are a common source of the more educated individuals that found the best startups. In order to pare down the sample to those most likely to be Schumpeterian entrepreneurs, we consider only individuals that work in and start businesses related to their education. Exploiting the panel nature of the data set, we explore the factors that influence workers to start businesses, the determinants of the earnings of new business founders relative to their earnings as workers, and the factors that influence the hazard of entrepreneurs returning to paid work. With the exception of some of the findings for older workers, our tests provide strong support for our model. We attribute the departures for older workers to our imperfect ability to pare from the sample workers that choose entrepreneurship for defensive reasons.

The paper is organized as follows. In Section II, we lay out our theoretical model of the Schumpeterian entrepreneur and derive various predictions. In Section III, we discuss data and methods. In Section IV we test the predictions of our model. In Section $\mathrm{V}$, the implications of our findings are discussed and concluding remarks are offered.

\section{Theory}

An extraordinary growth in knowledge has promoted specialization and the division of knowledge in society over time (Becker and Murphy [1992]). Our vision of a Schumpeterian entrepreneur, particularly one in engineering and the sciences, is an individual who has been formally educated and comes across a worthwhile idea while 
working in a firm, university, or government lab that exploits his or her education. Successful entrepreneurship results from a match between an individual's skills and an idea that exploits those skills (cf. Shane and Venkataraman [2000], Shane [2003]). When the person is particularly able and the idea particularly worthy, such a match can lead to significant returns. We now develop a stylized model that formalizes this idea.

\subsection{Set-up}

We assume that each individual $i$ is endowed with some innate ability $a_{i}$. This ability determines the individual's earnings as a worker, which is normalized to equal $a_{i}$. We assume that each individual also receives a business idea. The value of the idea depends on its intrinsic merit and the fit of the idea with the individual's skills. Let $\theta_{i}$ denote the value of individual $i$ 's entrepreneurial idea, which is assumed to be independent of $a_{i}$. If individual $i$ becomes an entrepreneur, his earnings depend on the quality of his idea interacted with his ability:

$$
x_{i}=a_{i}^{2} \theta_{i} .
$$

Entrepreneurial earnings are specified as a convex function of ability to capture the Schumpeterian notion that highly talented individuals can generate great returns in entrepreneurship.

We assume that as individuals gain experience as workers, they develop insights into the value of their entrepreneurial ideas. For one, they learn from work about the nature of their skills, which helps them judge the match between their skills and their idea. Further, they get a chance to observe peers that became entrepreneurs. This provides a better sense of the skills needed to be a successful entrepreneur and whether they have them. We model this process in the simplest possible three-period framework. In period 1 individuals do not know the value of $\theta_{i}$, but they do know that it is a draw from a normal distribution with mean 0 and variance $\sigma_{\theta}^{2}$. Accordingly, their (common) prior distribution for $\theta_{i}$ is $N\left(0, \sigma_{\theta}^{2}\right)$. At the end of period 1 , a worker receives a signal about $\theta_{i}$ given by

$$
z_{i}=\theta_{i}+w_{i}
$$


where $w_{i} \sim N\left(0, \sigma_{w}^{2}\right)$ and is independent of $\theta_{i}$ and $a_{i}$. This signal is used to update the subjective distribution for $\theta_{i}$ according to the well-known Bayesian learning mechanism. Hence, at the beginning of period 2, the posterior distribution for $\theta_{i}$ is distributed normally with mean $\hat{\mu}_{i}$ and variance $\hat{v}^{2}$, where

$$
\begin{aligned}
& \hat{\mu}_{i}=\sigma_{\theta}^{2} z_{i} /\left(\sigma_{\theta}^{2}+\sigma_{w}^{2}\right) \\
& \hat{v}^{2}=\sigma_{w}^{2} \sigma_{\theta}^{2} /\left(\sigma_{\theta}^{2}+\sigma_{w}^{2}\right) .
\end{aligned}
$$

The value of $\theta_{i}$ is then revealed at the end of period 2, so that in period 3 the true quality of the idea is known. Period 3 can be thought of as the individual's remaining time in the labor force as either a worker or an entrepreneur.

\subsection{Becoming an Entrepreneur}

As a cohort ages and some individuals choose to become entrepreneurs, the distribution of ability and quality of entrepreneurial ideas among the remaining workers may change, which in turn can influence the rate at which individuals in the cohort become entrepreneurs. Our interest, however, is on how learning by individuals about the quality of their ideas influences the rate at which they become entrepreneurs. Accordingly, we simplify by assuming that as a cohort ages, the distribution of ability and the quality of ideas among those who have not yet chosen to become entrepreneurs does not change. ${ }^{1}$

In period 1 the expected return from entrepreneurship equals 0 for all individuals, and everyone begins their career as a worker. In period 2 a worker chooses to become an entrepreneur if his expected earnings from entrepreneurship exceed his wage from work:

$$
a_{i}^{2} \hat{\mu}_{i}>a_{i} \text {, or } \hat{\mu}_{i}>1 / a_{i} \text {. }
$$

In period 3 there is no uncertainty, hence the condition for becoming an entrepreneur is

$$
a_{i}^{2} \theta_{i}>a_{i} \text { or } \theta_{i}>1 / a_{i} .
$$

\footnotetext{
1 This is consistent with the small fraction of paid workers who become entrepreneurs (as reported in the next section), suggesting that selection into entrepreneurship will have a minimal effect on the distribution of ability and ideas among the remaining workers.
} 
Since $\theta_{i}$ (and $\hat{\mu}_{i}$ ) are independent of $a_{i}$, it follows immediately from (5) and (6) that in every period more talented individuals are more likely to become entrepreneurs. Since workers earn a wage equal to $a_{i}$, it follows that:

Proposition 1: The probability of becoming an entrepreneur is an increasing function of the worker's wage for both young (i.e., period 2) and old (i.e., period 3) workers.

The rate of entrepreneurship and the ability of the individuals who become entrepreneurs changes as a cohort ages. It can be shown (see Chernoff [1968, p. 227]) that $\hat{\mu}_{i}$ is normally distributed with mean 0 and variance $S^{2} \equiv \sigma_{\theta}^{2}-\hat{v}^{2}$. Therefore, the probability of being an entrepreneur in period 2 can be expressed as:

$$
\operatorname{Pr}\left(\hat{\mu}_{i}>1 / a_{i}\right)=1-\operatorname{Pr}\left(\hat{\mu}_{i} / S \leq 1 /\left(a_{i} S\right)\right)=1-\Phi\left(1 / a_{i} S\right) \equiv \omega_{2}\left(a_{i}\right),
$$

where $\Phi(\cdot)$ is the cumulative distribution function of the standard normal distribution. In period 3 the quality of the business idea is known, so ignoring the "depletion" of the pool of potential entrepreneurs in period 2 the probability of becoming an entrepreneur is given by

$$
\operatorname{Pr}\left(\theta_{i}>1 / a_{i}\right)=1-\operatorname{Pr}\left(\theta_{i} / \sigma_{\theta} \leq 1 /\left(a_{i} \sigma_{\theta}\right)\right)=1-\Phi\left(1 / a_{i} \sigma_{\theta}\right) \equiv \omega_{3}\left(a_{i}\right) .
$$

Since $\sigma_{\theta}=\left(S^{2}+\hat{v}^{2}\right)^{1 / 2}>S$, (7) and (8) imply that the probability of becoming an entrepreneur rises with labor market experience for workers at every ability level:

Proposition 2: The probability of becoming an entrepreneur is an increasing function of the worker's labor market experience for any ability level (pre-entrepreneurship wage).

We can establish that the probability of becoming an entrepreneur rises with age more than proportionately for workers with lower ability levels. Let $\Omega_{2} \equiv \int_{0}^{\infty} \omega_{2}(a) d F(a)$ and $\Omega_{3} \equiv \int_{0}^{\infty} \omega_{3}(a) d F(a)$ denote the fractions of workers who become entrepreneurs in period 2 and period 3, respectively, where $d F(a)$ denotes the probability density function of $a$. For ability level $a$, define

$$
Z(a)=\frac{\omega_{2}(a)}{\Omega_{2}}-\frac{\omega_{3}(a)}{\Omega_{3}} .
$$

as the difference in the fraction of those becoming entrepreneurs in periods 2 and 3 with ability $a$. In the appendix we establish: 
Proposition 3: There is a threshold level of ability $\hat{a} \in(0, \infty)$ such that $Z(a) \geq 0$ for all $a \geq \hat{a}$ and $Z(a)<0$ for all $a<\hat{a}$.

Proposition 3 implies that the probability of becoming an entrepreneur rises with age by a greater proportion for those at lower ability levels. Intuitively, in period 2 half of all individuals at each ability level will get a signal with a positive value. Among those with very high ability (close to infinity), nearly all of those with a positive signal will become entrepreneurs in period 2, leaving little room for the number of such individuals that become entrepreneurs to rise in period 3. In contrast, few individuals of very low ability (close to 0 ) will get a signal in period 2 that would justify becoming an entrepreneur, leaving greater room for their numbers to rise in period 3. Consequently, those at lower ability levels will sustain a greater proportionate rise in their rate of entrepreneurship with age.

\section{$\underline{2.3 \text { Earnings of New Entrepreneurs }}$}

Among those individuals who become entrepreneurs in period 2, the difference between their expected earnings as entrepreneurs and their prior wage is $a_{i}^{2} \hat{\mu}_{i}-a_{i}>0$. Furthermore, $\partial\left(a_{i}^{2} \hat{\mu}_{i}-a_{i}\right) \partial \partial a_{i}=2 a_{i} \hat{\mu}_{i}-1>0$ given that $a_{i}^{2} \hat{\mu}_{i}-a_{i}>0$, so that the increase in expected earnings from entrepreneurship will be an increasing function of the pre-entrepreneurship wage. The same holds for $\hat{\mu}_{i}$ replaced by $\theta_{i}$ and hence applies as well for individuals that become entrepreneurs in period 3. Therefore:

Proposition 4: The difference between the average earnings of new entrepreneurs and their pre-entrepreneurship wage is positive and increasing in the pre-entrepreneurship wage.

Since the probability of becoming an entrepreneur rises with a worker's wage (Proposition 1), it follows from Proposition 4 that

Corollary 1: The average earnings of new entrepreneurs exceeds the average earnings of workers.

Given our assumption that the distribution of ability and hence wages among workers does not change as they age, Propositions 3 and 4 together imply:

Proposition 5: The difference between the average earnings of new entrepreneurs and their pre-entrepreneurship wage declines with labor market experience. 


\subsection{Persistence in Entrepreneurship}

Workers who become entrepreneurs at the beginning of period 3 know the quality of their entrepreneurial idea $\theta_{i}$ and hence will never exit from entrepreneurship. Workers who become entrepreneurs at the beginning of period 2 , on the other hand, do so on the basis of an imperfect signal about $\theta_{i}$. Some fraction of them will therefore discover at the end of the period that the true quality of the idea was below the cutoff given by (6) and will return to paid work. Therefore, our theory implies:

Proposition 6: The probability of exit from entrepreneurship is a decreasing function of an individual's labor market experience before becoming an entrepreneur.

We can compare the earnings of the entrepreneurs in period 2 that remain as entrepreneurs in period 3 with those that became entrepreneurs in period 3. Both groups are such that the value of their idea satisfies $\theta>1 / a$. But those that became entrepreneurs in period 2 also had to have an idea whose quality was sufficiently high that $\hat{\mu}_{i}>1 / a_{i}$, where $\hat{\mu}_{i}=\left[\sigma_{\theta}^{2} /\left(\sigma_{\theta}^{2}+\sigma_{w}^{2}\right)\right]\left(\theta_{i}+w_{i}\right)$. In the appendix, we show that for any given ability level $a_{i}$, in period 3 the average value of $\theta_{i}$ is greater for those individuals that became entrepreneurs in period 2 than period 3, which implies:

Proposition 7: For entrepreneurs of any ability level $a$, entrepreneurial earnings among continuing entrepreneurs are a decreasing function of the individual's labor market experience before becoming an entrepreneur.

Proof: See appendix.

A robust finding in the labor literature is that labor earnings increase with labor market experience, even controlling for tenure on the job. We will see in Section 4 that this holds for workers in our data as well. Proposition 7 implies the opposite result for entrepreneurs of any given ability. Based on simulations involving numerous alternative distributions for ability and alternative values for the relevant parameters, we have found this always holds as well for the average entrepreneur. We will test whether this theoretical implication holds on average for the entrepreneurs in our sample, in opposition to the result for the average worker in our sample. 


\section{Data and empirical methodology}

\subsection{The data}

The data come from the restricted-use Scientists and Engineers Statistical Data System (SESTAT) for the years 1995, 1997, and 1999 (http://sestat.nsf.gov/). The National Science Foundation administered national surveys of individuals with (at least) a. U.S. bachelor's degree in science or engineering to gather employment, education, and demographic information.

The surveys distinguish between workers and the self employed. The latter include individuals who reported that their principal employment was in their own business, professional practice, or farm. To test the theory, we equate entrepreneurship with self employment. It is unclear whether founders of firms like Intel, which had multiple founders and multiple initial shareholders, classify themselves as being employed in their own business at the time of the founding of their firms. If they do, it is also unclear whether they continue to classify themselves as being employed in their own business when the firm is sold or goes public. Surely these individuals qualify as entrepreneurs when they found their firms and possibly later as well when the firms are sold or go public. They are likely to be among the highest earning entrepreneurs. To the extent they are not classified as self employed in the data, the incidence of being self employed and the earnings of the self employed will be understated, particularly among the most talented individuals. The rate of exit from entrepreneurship may also be overstated, again particularly among the highest earning entrepreneurs. This will bias tests against various implications our model, particularly Propositions 1 and 4.

Respondents were asked to estimate their basic annualized salary if salaried or otherwise to estimate their earned income excluding business expenses. To make figures for different survey years comparable, we deflate earnings by the CPI. There are wellknown problems in measuring the earnings of the self employed (Hamilton [2000]). Earned income is not defined on the survey. If it is interpreted as net profit for tax purposes, it is likely to understate earnings due to liberal tax provisions for deductions such as depreciation, items used for personal as well as business purposes, etc. Earned income seemingly excludes capital gains. Salaries of workers also exclude capital gains, 
which are likely to be greater for the self employed than workers. Earned income and salaries exclude fringe benefits, which are likely to be greater for workers than the self employed. Perhaps it is not surprising then that findings about the earnings of the self employed relative to workers tend to be sensitive to the definition used for self-employed earnings (e.g., Hamilton [2000]). For the most part this will not be a problem for us. Most of our predictions about the earnings of the self employed involve how these earnings relative to those of workers vary according to pre-entrepreneurship earnings as workers and/or labor market experience. These predictions should hold even if our measure of self-employment earnings is biased up or down relative to workers' earnings.

Respondents reported their sex, race, marital status, whether handicapped, highest degree earned, age, tenure on the current job, and occupation, which we use as controls where relevant.

\section{$\underline{3.2 \text { Identifying potential Schumpeterian entrepreneurs }}$}

We noted in the introduction that a novel aspect of our approach is that we restrict the analysis to individuals who exploit their education in their job, as these are the individuals we feel most closely fit the notion of Schumpeterian entrepreneurship. In order to identify such individuals, we use the self-reported relation between the job and the highest educational degree. Respondents were asked whether their job was "closely related," "somewhat related," or "not related at all" to their educational degree, with about half of the individuals choosing the first answer. We consider only those who jobs were "closely related" to their degrees as potential Schumpeterian entrepreneurs. We refer to their employment as "technology related."2

\footnotetext{
${ }^{2}$ In an earlier working paper (Braguinsky and Ohyama [2007]) we matched the occupation in which an individual was employed with the major field in which he/she had earned the highest degree and assigned workers to the potential pool of Schumpeterian entrepreneurs based on the concentration of people from the same field in an occupation. The empirical results were qualitatively very similar, but one disadvantage of the earlier approach is that some occupation classes had to be defined rather broadly to ensure a sufficient number of observations, leading to an artificial reduction in the education-concentration index.
} 
Table 1: Human capital differences according to the relationship between job and education

\begin{tabular}{|l|l|r|r|r|}
\hline & $\begin{array}{l}\text { Job and } \\
\text { highest } \\
\text { degree: }\end{array}$ & $\begin{array}{l}\text { Closely } \\
\text { related }\end{array}$ & $\begin{array}{l}\text { Somewhat } \\
\text { related }\end{array}$ & $\begin{array}{l}\text { Not related } \\
\text { at all }\end{array}$ \\
\hline \multirow{2}{*}{$\begin{array}{l}\text { Undergraduate GPA 3.75 } \\
\text { and higher (mostly A) }\end{array}$} & Paid workers & 0.163 & 0.110 & 0.077 \\
\cline { 2 - 5 } & Self employed & 0.198 & 0.095 & 0.125 \\
\hline \multirow{2}{*}{$\begin{array}{l}\text { Undergraduate GPA 2.75 } \\
\text { and lower (half C or worse) }\end{array}$} & Paid workers & 0.113 & 0.147 & 0.171 \\
\cline { 2 - 5 } & Self employed & 0.104 & 0.210 & 0.236 \\
\hline \multirow{2}{*}{$\begin{array}{l}\text { Fathers with some graduate } \\
\text { or professional education }\end{array}$} & Paid workers & 0.243 & 0.226 & 0.215 \\
\cline { 2 - 5 } & Self employed & 0.240 & 0.196 & 0.194 \\
\hline \multirow{2}{*}{$\begin{array}{l}\text { Primary work activity new } \\
\text { technology related }\end{array}$} & Paid workers & 0.454 & 0.279 & 0.093 \\
\cline { 2 - 5 } & Self employed & 0.202 & 0.127 & 0.053 \\
\hline \multirow{2}{*}{$\begin{array}{l}\text { Work new technology } \\
\text { related: recent college grads }\end{array}$} & Paid workers & 0.404 & 0.219 & 0.046 \\
\cline { 2 - 5 } & Self employed & 0.302 & 0.095 & 0.056 \\
\hline
\end{tabular}

Note: all pair wise differences in means of corresponding fractions are statistically significant at 0.001 level using a two-tailed $t$-test except the difference between the fractions of fathers with some graduate or professional education in the "somewhat related" versus "not related at all" self-employed category (which is not statistically significant at a conventional level). Source: authors' estimates using the NSF data.

Table 1 provides information for the three groups defined by the relationship between their job and education. Those whose jobs were closely related to their education (i.e., the technology-related group) fared better in college. ${ }^{3}$ Judging from the higher education of their fathers, their superior education may have been family related. Those whose jobs were closely related to their education were also more likely to perform work involving new technology. ${ }^{4}$ This was true for all individuals and also for recent college graduates as reflected in the last row of Table 1. The differences are comparable whether one looks at all individuals together or separately for workers and the self employed.

\footnotetext{
${ }^{3}$ The GPA is available only for recent college graduates who comprise about $1 / 3$ of the SESTAT data.

${ }^{4}$ Based on the SESTAT classification of primary work activities, new-technology-related activities are defined to include: 1) basic research; 2) applied research; 3) development of materials and devices using knowledge gained from research; and 4) design of equipment, processes, structures, and models.
} 


\subsection{The sample and its basic characteristics}

In our empirical analysis, we exclude retired, unemployed, part-time workers, workers over 65 , and those who report salaries of zero as many of these individuals are likely to become self employed for defensive or life-style reasons. We also exclude occupations with almost no self employed, such as teaching, and occupations where sole proprietorships and partnerships are a common way of organizing activity, which includes health-related occupations, lawyers, judges, and agricultural occupations. See Table A1 for the list of occupations used.

We exploit the longitudinal nature of SESTAT by restricting the sample to individuals that were surveyed at least twice over the three survey years of 1995, 1997, and 1999. To be included in our sample, individuals had to classify their job or business as closely related to their education in all years they were surveyed. In total, our sample is composed of 20,204 individuals with 48,030 observations across the three survey years, with 3,850 of the observations (on 1,570 individuals) reflecting self-employment in at least one year.

We constructed an analogous data set for individuals that met all the above criteria except consistently being employed in technology-related positions. We call this the non-technology-related sample, which is composed of 16,930 individuals $(1,804$ of them self employed in at least one year) and 40,315 total observations (4,404 of those on self employed in at least one year). ${ }^{5}$ Table 2 presents summary statistics on earnings and demographics of workers and the self employed in the technology-related sample.

The self employed have much higher average earnings than workers. They are also older, have longer tenure in their current position, more likely to be white, and more likely to have Ph.D. degrees, although workers have a somewhat higher fraction of individuals with M.A. degrees. If we look at the same summary statistics for nontechnology workers (not reported) they look similar, but average earnings of the self employed are lower than those of workers even though the self employed are older and have longer job tenures.

\footnotetext{
${ }^{5}$ The total data set is composed of 292,010 observations for the three survey years, so the technologyrelated and non-technology-related samples constituted 30.3 percent of all the observations.
} 
Table 2: Summary statistics

\begin{tabular}{|l|l|r|r|r|r|}
\hline & & \multicolumn{2}{l|}{ Unbalanced panel } & \multicolumn{2}{l|}{ Balanced panel } \\
\hline & & \multicolumn{1}{l|}{$\begin{array}{l}\text { Paid } \\
\text { workers }\end{array}$} & $\begin{array}{l}\text { Self } \\
\text { employed }\end{array}$ & $\begin{array}{l}\text { Paid } \\
\text { workers }\end{array}$ & $\begin{array}{l}\text { Self } \\
\text { employed }\end{array}$ \\
\hline \multirow{3}{*}{ Annualized real salary } & Mean & 61,855 & 73,075 & 63,949 & 74,521 \\
\cline { 2 - 6 } Age & St.Dev. & 32,547 & 51,403 & 30,787 & 45,093 \\
\hline \multirow{3}{*}{ Tenure } & Mean & 41.37 & 45.96 & 42.09 & 45.91 \\
\cline { 2 - 6 } & St.Dev. & 9.01 & 8.30 & 8.54 & 7.94 \\
\hline Fractions of: Male & Mean & 7.16 & 8.51 & 7.88 & 8.93 \\
\cline { 2 - 6 } & St.Dev. & 7.10 & 7.39 & 7.18 & 7.40 \\
\hline \multicolumn{2}{|c|}{ White } & 0.756 & 0.769 & 0.781 & 0.794 \\
\hline \multicolumn{2}{|c|}{ M.A. degree holders } & 0.754 & 0.853 & 0.779 & 0.873 \\
\hline \multicolumn{2}{|c|}{ Ph.D. degree holders } & 0.282 & 0.259 & 0.296 & 0.262 \\
\hline \multicolumn{2}{|c|}{ Professional degree holders } & 0.365 & 0.424 & 0.330 & 0.407 \\
\hline Number of observations & 44,1804 & 0.007 & 0.005 & 0.008 \\
\hline Number of individuals & 18,634 & 1,550 & 20,736 & 2,130 \\
\hline
\end{tabular}

Source: authors' estimates using the NSF data.

\section{Empirical results}

Empirical analyses are reported in order of the propositions.

\subsection{Who Becomes An Entrepreneur: Testing Propositions 1, 2, and 3}

Proposition 1 predicts that at any given level of labor market experience, higherearning workers will be more likely to become entrepreneurs. Furthermore, Propositions 2 and 3 predict that the fraction of workers at every earnings level that become entrepreneurs will rise with labor market experience, especially so at lower earnings levels. We also expected that workers with longer tenure on the job would be less likely to change their jobs, including switching to self employment. We can test these predictions by estimating the following probit equation:

$$
\operatorname{Pr}\left(S E_{t+1}=1\right)=\Phi\left(\alpha+\beta_{1} w_{t}+\beta_{2} \operatorname{lex}_{t}+\beta_{3} w_{t} \times \text { lex }_{t}+\beta_{4} t e n_{t}+\delta X\right),
$$

where $\Phi$ is the c.d.f. of the standard normal distribution, $S E_{t+1}$ is a 1-0 dummy variable equal to 1 if a worker in period $t$ is self employed in period $t+1, w_{t}$ denotes paid earnings

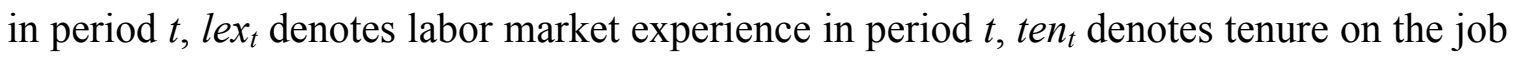
in period $t$, and $X$ is a vector of demographic and occupational controls, including dummies for an MA degree, Ph.D. degree, professional degree, gender, white, married, handicapped, year, and 34 separate occupations (listed in Table A1 in the appendix). We 
also estimated (10) under the assumptions of the linear probability model and logistic distribution and the results were very similar.

Table 3: Testing Propositions 1, 2, and 3

\begin{tabular}{|l|l|r|l|r|}
\hline \multicolumn{2}{|l|}{ Independent variable } & & & $\begin{array}{l}\text { Marginal effects } \\
\text { at the mean }\end{array}$ \\
\hline \multirow{3}{*}{ Log real salary } & Coefficient & 0.285 & $* *$ & 0.0107 \\
\cline { 2 - 5 } & St. Error & 0.114 & & 0.0055 \\
\hline \multirow{4}{*}{$\begin{array}{l}\text { Labor experience } \\
\text { Log real salary interacted } \\
\text { with labor experience }\end{array}$} & Coefficient & 0.145 & $* * *$ & -0.0004 \\
\cline { 2 - 5 } Tenure & St. Error & 0.051 & & -0.0006 \\
\cline { 2 - 5 } & Coefficient & -0.012 & $* *$ & \\
\hline \multirow{3}{*}{ Constant Error } & 0.005 & & \\
\hline Other controls included & Coefficient & -0.016 & $* * *$ & \\
\cline { 2 - 5 } & St. Error & 0.003 & & \\
\hline Number of observations (individuals) & Coefficient & -4.609 & $* * *$ & \\
\cline { 2 - 5 } & St. Error & 1.248 & & \\
\hline Log (pseudo)likelihood & & \multicolumn{2}{|c|}{ Yes } & \\
\hline
\end{tabular}

The dependent variable is a 1-0 dummy equal to 1 for individuals that moved from work in period $t$ to self employment in period $t+1$. Other controls are master, Ph.D. and professional degree dummies, white, male, married and handicapped dummies, year dummies and 34 occupational dummies. Robust clustered standard errors are reported. *** indicates that the coefficient is significant at 1 percent level, ** at 5 percent level, and * at 10 percent level. Source: authors' estimates using the NSF data.

The estimates of equation (10) are reported in Table 3. The estimates of $\beta_{1}, \beta_{2}$, and $\beta_{3}$ all conform with the predictions of the theory. The estimate of $\beta_{1}$ is positive and significant at the .05 level, indicating that the probability of becoming an entrepreneur rises with pre-entrepreneurial earnings. The estimate of $\beta_{2}$ is also positive and significant at the .01 level, indicating that the probability of becoming an entrepreneur rises with labor market experience. The estimate of $\beta_{3}$ is negative and significant at the .05 level, consistent with the probability of becoming an entrepreneur rising most with labor market experience for those at lower earnings/ability levels. The estimate of $\beta_{4}$ is negative and significant at the .01 level, consistent with greater tenure on the job lowering the probability of changing one's position. The demographic and occupational controls are jointly significant at the .01 level. The annual predicted probability of becoming an entrepreneur ranges from 1.33 percent for workers under age 29 in the lowest labor 
market experience decile to 2.8 percent for workers above age 53 in the highest labor market experience decile.

Proposition 1 predicts that the probability of becoming an entrepreneur should be an increasing function of earnings for every level of labor market experience. This requires $\beta_{1}+\beta_{3}$ lex $_{t}$ to be positive for all values of lex . The estimates of $\beta_{1}$ and $\beta_{3}$ are such that this condition holds for $l e x_{t}$ up to 24 years. Since this corresponds to age 46 for those that entered the labor force at age 22, clearly the probability of becoming an entrepreneur is not increasing in earnings for older individuals. Proposition 2 predicts that the probability of becoming an entrepreneur should rise with labor market experience at every wage. This requires $\beta_{2}+\beta_{3} w_{t}$ to be positive for all values of $w_{t}$. Based on the coefficient estimates, this condition is satisfied for all workers in the data set.

To better understand the relationship between the probability of becoming an entrepreneur and earnings, we divided observations into six groups according to whether the worker was above or below age 45 and whether the worker was in the bottom, middle, or upper third of the earnings distribution (given his age). Table 4 reports the annual fraction of workers in each group that became entrepreneurs.

Table 4: Fraction of workers becoming self employed by age and earnings

\begin{tabular}{|l|r|r|}
\hline Paid earnings & Under 45 & 45 and over \\
\hline Lower third & 1.79 & 3.12 \\
\hline Middle third & 1.24 & 1.90 \\
\hline Upper third & 2.43 & 2.85 \\
\hline
\end{tabular}

Source: authors' estimates using the NSF data

For workers below age 45, the fraction of workers becoming an entrepreneur is highest among the highest paid workers, consistent with our theory, but is unexpectedly greater among those in the bottom than middle third of the wage distribution. For workers above age 45, the fraction becoming an entrepreneur in each earnings group is greater than for the respective earnings group below age 45, also consistent with the theory. But the fraction of workers becoming entrepreneurs among the older workers is unexpectedly highest in the lowest third of the earnings distribution. Equation (10) constrains the probability of becoming an entrepreneur to change monotonically with earnings and thus cannot accommodate the non-monotonic patterns evident in Table 4, 
especially for the more experienced workers. It would appear that this is why the estimates of equation (10) imply that $\beta_{1}+\beta_{3}$ lex turns negative at greater levels of lex $x_{t}$ We will return in the next section to address why we think this departure from the model occurs.

\section{$\underline{4.2 \text { Earnings of New Entrepreneurs: Testing Propositions } 4 \text { and } 5}$}

Proposition 4 predicts that workers that become entrepreneurs will increase their earnings, with the increase greater for workers with greater pre-entrepreneurship earnings. Proposition 5 predicts that the increase in earnings from becoming an entrepreneur will decline with labor market experience. This suggests the following empirical specification:

$$
\ln s e_{t+1}-\ln w_{t}=\alpha+\beta_{1} \ln w_{t}+\beta_{2} l e x_{t}+\gamma X+\varepsilon_{t},
$$

where $s e_{t+1}$ are the earnings of workers in period $t$ that are self employed in period $t+1, w_{t}$ are the earnings of the workers in period $t$, lex $x_{t}$ is the labor market experience of the workers in period $t, X$ is the set of demographic and occupational controls, and $\varepsilon_{t}$ is the disturbance term.

If earnings from work, $w_{t}$, were purely a reflection of an individual's ability, then there would be no problem estimating equation (11). But earnings from work will vary from year to year due to factors such as the availability of overtime work. Annual earnings are also likely to be measured with error. Both factors will contribute to a negative correlation between the dependent variable in (11) and earnings, which in turn will cause OLS estimates of $\beta_{1}$ to be negatively biased. The same would be true if the dependent variable in (11) were $\ln w_{t+1}-\ln w_{t}$, which might be expected to be unrelated to $\ln w_{t}$ if earnings were measured correctly and did not contain a transitory component. Symptomatic of the difficulties of estimating equation (11) is that when we did estimate equation (11) with $\ln w_{t+1}-\ln w_{t}$ as the dependent variable, the estimate of $\beta_{l}$ was negative and significant at the .01 level.

If the random component of wages due to transitory factors and measurement error are uncorrelated across years, we can estimate consistently the coefficients of (11) using $\ln w_{t-1}$ as an instrument for $\ln w_{t}$. We report these instrumental-variable estimates in Table 5. They are based on the 161 individuals in our data set that were surveyed in all 
three years and reported being a worker in 1995 and 1997 and self employed in 1999. We also present in Table 5 the coefficient estimates of the same model restricted to the 6,986 individuals that reported being a worker in all three survey years, with $\ln w_{t+1}$ substituted for $\ln s e_{t+l}$. To increase the precision of our estimates, we drop all the demographic and occupational control variables, which perhaps not surprisingly are jointly insignificant. ${ }^{6}$

Table 5: Testing Propositions 4 and 5

\begin{tabular}{|c|c|c|c|c|c|}
\hline \multirow{2}{*}{\multicolumn{2}{|c|}{$\begin{array}{l}\text { First stage regression } \\
\text { Paid workers in } t-1 \text { and in } t\end{array}$}} & \multirow{2}{*}{\multicolumn{4}{|c|}{$\begin{array}{c}\text { Self employed in } t+1 \\
\text { Log earnings in } t\end{array}$}} \\
\hline & & & & & \\
\hline \multirow[b]{2}{*}{ Log earnings in $t-1$} & Coefficient & 0.426 & $* * *$ & 0.517 & $* * *$ \\
\hline & St. Error & 0.048 & & 0.008 & \\
\hline \multirow[b]{2}{*}{ Labor experience } & Coefficient & 0.006 & & 0.005 & $* * *$ \\
\hline & St. Error & 0.004 & & 0.000 & \\
\hline \multirow[b]{2}{*}{ Constant } & Coefficient & 6.331 & $* * *$ & 5.271 & $* * *$ \\
\hline & St. Error & 0.524 & & 0.082 & \\
\hline \multicolumn{2}{|l|}{ R squared } & 0.347 & & 0.441 & \\
\hline \multicolumn{2}{|c|}{ Second stage regression } & \multicolumn{4}{|c|}{ Log earnings in $t+1-$ Log earnings in $t$} \\
\hline \multirow{2}{*}{$\begin{array}{l}\text { Log earnings in } t \\
\text { (instrumented) }\end{array}$} & Coefficient & 0.500 & $* * *$ & -0.045 & $* * *$ \\
\hline & St. Error & 0.189 & & 0.016 & \\
\hline \multirow[b]{2}{*}{ Labor experience } & Coefficient & -0.012 & $*$ & -0.005 & $* * *$ \\
\hline & St. Error & 0.007 & & 0.001 & \\
\hline \multirow[b]{2}{*}{ Constant } & Coefficient & -5.303 & $* *$ & 0.670 & $* * *$ \\
\hline & St. Error & 2.073 & & 0.169 & \\
\hline \multicolumn{2}{|c|}{ Number of observations } & 161 & & 6,986 & \\
\hline \multicolumn{2}{|c|}{ Joint significance test statistic (Prob $>$ F) } & 0.020 & & 0.000 & \\
\hline
\end{tabular}

Two-stage least squares estimation is employed, with log earnings in period $t$ estimated in the first stage as a function of log earnings in period $t-1$ and labor experience. *** indicates that the coefficient is significant at 1 percent level, ${ }^{* *}$ at 5 percent level, and * at 10 percent level. Source: authors' estimates using the NSF data.

Both coefficient estimates for the regression with $\ln s e_{t+1}-\ln w_{t}$ as the dependent variable are consistent with the theory. The estimate of $\beta_{1}$ is positive and significant at the .01 level, indicating that the increase in earnings from entrepreneurship is greater for workers with higher (pre-entrepreneurship) earnings. The estimate of $\beta_{2}$ is negative and significant at the .10 level, indicating that the gain in earnings from entrepreneurship is lower for individuals with greater labor market experience. Note that when $\ln w_{t+1}-\ln w_{t}$

\footnotetext{
${ }^{6}$ Annual changes in earnings are difficult to explain and would not be expected to be related to demographic or occupational factors on a regular basis.
} 
is used as the dependent variable and the model is estimated using the same instrumentalvariable strategy, the estimate of $\beta_{l}$ is negative and significant at the .01 level. This suggests that the estimates for those becoming entrepreneurs are not an artifact of the estimation procedure or form of the model.

The corollary to Proposition 4 predicts that the average earnings of new entrepreneurs will exceed the average earnings of workers. We can test this prediction without having to resort to the instrumental-variable approach by estimating the following equation:

$$
\ln \text { earn }_{t+1}=\alpha+\beta_{1} D_{t+1}+\beta_{2} D_{t+1} \text { lex }_{t}+\beta_{3} \text { lex }_{t}+\gamma X+\varepsilon_{t},
$$

where $\ln e^{a r n} n_{t+1}$ is the log of the individual's wage or self-employment earnings in period $t+1, D_{t+1}$ is a 1-0 dummy variable equal to 1 for individuals that shift from work to self employment in period $t+1$, lex $x_{t}$ is labor market experience in period $t, X$ is the set of demographic and occupational controls, and $\varepsilon_{t}$ is the disturbance term. The variable $l e x_{t}$ is included to allow for earnings, whether at work or self employment, to increase with labor market experience, and $D_{t+1}$ is interacted with $l e x_{t}$ to allow the effect on earnings of becoming an entrepreneur to decline with labor market experience, as predicted in Proposition 5. The demographic and occupational controls are included to allow for general factors expected to influence earnings for all individuals.

The estimates of this model are reported in Table 6. Considering first the controls, the estimate of the coefficient of labor market experience, $\beta_{3}$, is positive and significant at the .01 level, as would be expected. The demographic and occupational controls are jointly significant at the .01 level, also as expected. In terms of the theory, the estimate of $\beta_{l}$ is positive and significant at the .01 level, as predicted. It implies that among individuals with no prior labor market experience, the newly self employed earn about 20 percent more than comparable workers. The estimate of $\beta_{2}$ is negative and significant at the .01 level and implies that each prior year of labor market experience decreases the self employed-worker earnings differential by about 0.8 percent. Consequently, for those with 25 years of labor market experience, the newly self employed earn about the same amount as comparable workers, and for yet older individuals the newly self employed earn less than workers. 
Table 6: Average earnings of new entrepreneurs versus workers

\begin{tabular}{|l|l|r|r|}
\hline Dependent variable & & Log $t+1$ earnings \\
\hline \multirow{3}{*}{ Mobility dummy } & Coefficient & 0.179 & $* * *$ \\
\cline { 2 - 5 } $\begin{array}{l}\text { Mobility dummy interacted } \\
\text { with labor experience }\end{array}$ & St. Error & 0.070 & \\
\hline \multirow{3}{*}{ Labor experience } & Coefficient & -0.008 & $* * *$ \\
\cline { 2 - 5 } & St. Error & 0.003 & \\
\hline \multirow{3}{*}{ Constant } & Coefficient & 0.012 & $* * *$ \\
\cline { 2 - 5 } & St. Error & 0.000 & \\
\hline Other controls included & Coefficient & 10.148 & $* * *$ \\
\cline { 2 - 5 } & St. Error & 0.178 & \\
\hline Number of observations (individuals) & \multicolumn{3}{|c|}{ Yes } \\
\hline R-squared & & \multicolumn{3}{|c|}{$0.29(19,250)$} \\
\hline
\end{tabular}

Mobility dummy equals 1 if the individual moved from paid work in period $t$ into self employment in period $t+1$. Other controls included are master, Ph.D. and professional degree dummies, white, male, married and handicapped dummies, year dummies and 34 occupational dummies. Reported are robust clustered standard errors. *** indicates that the coefficient is significant at 1 percent level, $* *$ at 5 percent level, and $*$ at 10 percent level. Source: authors' estimates using the NSF data

Our theory predicts that new entrepreneurs earn more than comparable workers, albeit the differential is expected to be less for those with greater labor market experience. The lower relative earnings of the newly self employed at older ages could reflect a downward bias in the measure of the earnings of the self employed relative to workers. In the next section we provide an alternative explanation for this departure from the theory, attributing it to the same factors we conjecture are behind the high rate of entrepreneurship among older individuals at low earnings levels.

Elfenbein et al. (2008) find that in the SESTAT data set, employees of smaller firms are significantly more likely to enter self employment than employees of larger firms. This also holds in our restricted, technology-related sample. Workers in small firms also earn less than workers in large firms. Consequently, if we include the size of the worker's employer in equation (12) to control for the types of workers more likely to become self employed, the estimates conform even more with our theory. The estimate of $\beta_{1}$ increases by about 50 percent. Furthermore, the new estimates of $\beta_{1}$ and $\beta_{2}$ together 
imply that the newly self employed now earn more than comparable workers among individuals with up to 32 years of labor market experience. ${ }^{7}$

\subsection{Persistence in Entrepreneurship: Testing Propositions 6 and 7.}

Proposition 6 predicts that the greater the amount of labor experience before becoming an entrepreneur, the less likely an entrepreneur will return to being a worker. For continuing entrepreneurs in our sample we do not know exactly when they became self employed, but we can subtract tenure in the current business from labor market experience to obtain a proxy for labor market experience prior to entrepreneurship. We expect those with higher earnings and tenure at entrepreneurship to be less likely to return to being a worker. Thus, we test Proposition 6 by estimating the following probit model:

$$
\operatorname{Pr}\left(P W_{t+1}=1\right)=\Phi\left(\alpha+\beta_{1} \text { prior_lex }_{t}+\gamma_{1} \text { entearn }_{t}+\gamma_{2} \text { ten }_{t}+\delta X\right),
$$

where $P W_{t+1}$ is a 1-0 dummy equal to 1 if a self-employed individual in period $t$ is a worker in period $t+1$, prior_lex $x_{t}$ is labor market experience in period $t$ prior to the current business, entearn $n_{t}$ is log entrepreneurial earnings in period $t$ ten $_{t}$ is tenure in period $t$, and $X$ is the set of demographic and occupational controls.

The estimates of (13) are reported in Table 7. Our findings are quite different for younger and older entrepreneurs and so we report separate estimates for entrepreneurs under 45 and those 45 and above. Consider first the estimates for the younger entrepreneurs. The estimate of $\beta_{1}$ is negative and significant at .05 level, consistent with the theory. The estimate of $\gamma_{1}$ is negative and significant at the .05 level and the estimate of $\gamma_{2}$ is negative and significant at the .10 level, consistent with longer entrepreneurial tenure and greater entrepreneurial earnings lowering the probability of returning to being a worker. The demographic and occupational controls are jointly significant at the .01 level. The estimates of $\beta_{1}$ and $\gamma_{1}$ imply that each additional year of prior labor market experience lowers the hazard of exit from entrepreneurship by 1.4 percent (calculated using marginal effects at the mean) and each additional year of tenure lowers the hazard

\footnotetext{
${ }^{7}$ As Elfenbein et al. (2008) point out, the future self employed may choose to work in firms of smaller size because they provide better entrepreneurial training. If so, estimating (12) without a firm size control seems to be the right empirical strategy.
} 
by about the same magnitude. In contrast to the estimates for the younger entrepreneurs, none of the coefficient estimates for self-employed individuals of age 45 and higher is significant at conventional levels except for the demographic controls, which are jointly significant at the .01 level.

Table 7: Testing Proposition 6

\begin{tabular}{|c|c|c|c|c|c|}
\hline \multicolumn{2}{|l|}{ Independent variable } & \multicolumn{2}{|c|}{ Younger entrepreneurs } & \multicolumn{2}{|c|}{ Older entrepreneurs } \\
\hline \multirow{2}{*}{$\begin{array}{l}\text { Labor experience, minus } \\
\text { tenure (experience at entry) }\end{array}$} & Coefficient & -0.038 & $* *$ & -0.003 & \\
\hline & St. Error & 0.016 & & 0.012 & \\
\hline \multirow[b]{2}{*}{ Tenure in business } & Coefficient & -0.038 & $* *$ & -0.015 & \\
\hline & St. Error & 0.017 & & 0.012 & \\
\hline \multirow[b]{2}{*}{ Log earnings } & Coefficient & -0.154 & $*$ & 0.088 & \\
\hline & St. Error & 0.082 & & 0.064 & \\
\hline \multirow[b]{2}{*}{ Constant } & Coefficient & 2.332 & $*$ & -1.553 & \\
\hline & St. Error & 1.239 & & 1.091 & \\
\hline \multicolumn{2}{|c|}{ Other controls included } & \multicolumn{2}{|l|}{ Yes } & \multicolumn{2}{|c|}{ Yes } \\
\hline \multicolumn{2}{|c|}{ Number of observations (individuals) } & \multicolumn{2}{|c|}{$627(523)$} & \multicolumn{2}{|l|}{$871(679)$} \\
\hline \multicolumn{2}{|c|}{ Log (pseudo)likelihood } & \multicolumn{2}{|c|}{-366.94} & \multicolumn{2}{|l|}{-452.31} \\
\hline
\end{tabular}

The dependent variable is the dummy which equals 1 if the individual moved from self employment in period $t$ to work in period $t+1$. Younger entrepreneurs are those less than 45 year old and older entrepreneurs are between 45 and 65 years old. Other controls include master, Ph.D. and professional degree dummies, white, male, married and handicapped dummies, year dummies and 34 occupational dummies. Robust clustered standard errors are reported. $* * *$ indicates that the coefficient is significant at 1 percent level, ** at 5 percent level, and $*$ at 10 percent level. Source: authors' estimates using the NSF data.

Finally, based on Proposition 7 we expect that for continuing entrepreneurs, entrepreneurial earnings should be decreasing in pre-entry labor market experience. We also expected entrepreneurial earnings to rise with tenure. Accordingly, we estimate the following equation:

$$
\text { Inentearn } t_{t}=\alpha+\beta_{1} \text { prior }_{-} \text {lex }_{t}+\beta_{2} \text { tenure }_{t}+\delta X+\varepsilon_{t}
$$

where entearn $n_{t}$ is entrepreneurial earnings in period $t$, prior_lex $x_{t}$ is labor market experience in period $t$ prior to the current business, tenure $_{t}$ is tenure in the current business in period $t$, and $X$ is the set of demographic and occupational controls.

We estimate equation (14) for all entrepreneurs and then separately for those with tenure greater than the median and greater than the $75^{\text {th }}$ percentile to correspond more closely to the idea of continuing entrepreneurs. For comparison, we also estimated equation (14) for workers, with log entrepreneurial earnings replaced by the log of wages. 
Table 8. Self employed and paid earnings as a function of labor experience and tenure in the current business (job).

\begin{tabular}{|c|c|c|c|c|c|c|}
\hline & $\begin{array}{l}\text { Independent } \\
\text { variable }\end{array}$ & $\begin{array}{l}\text { Coeffici } \\
\text { ent }\end{array}$ & $\begin{array}{l}\text { St. } \\
\text { Error }\end{array}$ & & $\begin{array}{l}\text { \# of observations } \\
\text { (individuals) }\end{array}$ & $\begin{array}{l}\text { R- } \\
\text { squared }\end{array}$ \\
\hline \multirow[b]{3}{*}{ Entrepreneurs } & Prior labor exp. & -0.009 & 0.003 & $* * *$ & \multirow[b]{3}{*}{$2,659(1,554)$} & \multirow[b]{3}{*}{0.118} \\
\hline & Tenure & 0.008 & 0.003 & *** & & \\
\hline & Constant & 10.659 & 0.090 & *** & & \\
\hline \multirow{3}{*}{$\begin{array}{l}\text { Entrepreneurs } \\
\text { with tenure > } \\
\text { median }\end{array}$} & Prior labor exp. & -0.021 & 0.005 & $* * *$ & \multirow[b]{3}{*}{$1,296(752)$} & \multirow[b]{3}{*}{0.151} \\
\hline & Tenure & -0.000 & 0.005 & & & \\
\hline & Constant & 11.047 & 0.143 & $* * *$ & & \\
\hline \multirow{3}{*}{$\begin{array}{l}\text { Entrepreneurs } \\
\text { with tenure }> \\
\text { 75th percentile }\end{array}$} & Prior labor exp. & -0.034 & 0.008 & $* * *$ & \multirow[b]{3}{*}{$629(382)$} & \multirow[b]{3}{*}{0.200} \\
\hline & Tenure & 0.001 & 0.009 & & & \\
\hline & Constant & 11.258 & 0.306 & $* * *$ & & \\
\hline \multirow[b]{3}{*}{ Workers } & Prior labor exp. & 0.012 & 0.000 & $* * *$ & \multirow[b]{3}{*}{$43,467(19,014)$} & \multirow[b]{3}{*}{0.307} \\
\hline & Tenure & 0.017 & 0.000 & $* * *$ & & \\
\hline & Constant & 10.174 & 0.095 & $* * *$ & & \\
\hline \multirow{3}{*}{$\begin{array}{l}\text { Workers with } \\
\text { tenure }> \\
\text { median }\end{array}$} & Prior labor exp. & 0.005 & 0.001 & $* * *$ & \multirow[b]{3}{*}{$20,851(11,403)$} & \multirow[b]{3}{*}{0.237} \\
\hline & Tenure & 0.012 & 0.001 & $* * *$ & & \\
\hline & Constant & 9.888 & 0.180 & $* * *$ & & \\
\hline \multirow{3}{*}{$\begin{array}{l}\text { Workers with } \\
\text { tenure }>75 \text { th } \\
\text { percentile }\end{array}$} & Prior labor exp. & 0.002 & 0.001 & $*$ & \multirow[b]{3}{*}{$10,057(5,656)$} & \multirow[b]{3}{*}{0.209} \\
\hline & Tenure & 0.008 & 0.001 & $* * *$ & & \\
\hline & Constant & 10.525 & 0.222 & $* * *$ & & \\
\hline
\end{tabular}

The dependent variable is log earnings. Other controls include master, Ph.D. and professional degree dummies, white, male, married and handicapped dummies, year dummies and 34 occupational dummies. Robust clustered standard errors are reported. *** means that the coefficient is significant at 1 percent level, ** at 5 percent level, and * at 10 percent level. Source: authors' estimates using the NSF data.

Estimates of equation (14) are presented in Table 8. For all entrepreneurs, the estimate of $\beta_{l}$ is negative and significant at the .01 level, suggesting that entrepreneurial earnings decline with labor market experience prior to becoming an entrepreneur. As we restrict the sample to the longer-lived entrepreneurs, the negative effect of preentrepreneurship labor market experience becomes much more pronounced, as would be expected based on Proposition 7. Greater tenure has an independent effect of increasing entrepreneurial earnings in the total sample, as expected, but not when the sample is restricted to entrepreneurs with longer tenure. For workers, greater tenure increases earnings, particularly for the whole sample. In contrast to entrepreneurs, however, labor market experience prior to starting the current job consistently increases earnings for all 
workers and those above the median and $75^{\text {th }}$ percentile. Thus, we see a sharp contrast between entrepreneurs and workers in terms of the effects of labor market experience on earnings.

\section{Discussion}

Our main goal was to test Schumpeter's theory of entrepreneurship using a novel data set on the self employed. The fact that self employment generates positive returns compared to paid work at the top tier of the earnings distribution has been well documented in the literature (e.g., Hamilton [2000]). Past studies have left it unclear, however, whether this was simply due to higher variance in self-employed earnings or to more systematic factors. Past studies also showed self employment apparently producing negative returns at the median and even on average, making many skeptical of inferences about entrepreneurship drawn from data on the self employed.

Our dataset is composed of highly educated individuals in engineering and science, which by its nature should contain a larger proportion of self employed that are true Schumpeterian entrepreneurs than nationally representative samples. Furthermore, we restrict the sample to those who work in technology-related jobs to eliminate even more of the questionable self employed without resorting to criteria such as high income or the presence of venture capital funding that prefigure entrepreneurial success. We also have repeated observations on the same individuals, so we can look at how the choice of becoming an entrepreneur and returning to work varies according to earnings and labor market experience prior to becoming an entrepreneur.

To take advantage of these novel attributes of the data, we developed a theory that addresses certain key issues in the choice between working for pay and becoming an entrepreneur. Entrepreneurial earnings depend on the match between an individual's ability and the uncertain quality of his entrepreneurial idea. In accordance with Schumpeter's view, we postulated a convex effect of ability on entrepreneurial earnings, so that the most talented individuals earn the greatest premium from entrepreneurship. We conjectured that uncertainty about entrepreneurial ideas gets resolved with labor market experience, which yields the distinctive prediction that labor market experience affects the inclination to become an entrepreneur most strongly for those of lesser ability. 
The theory also predicts that while individuals with less pre-entrepreneurship labor market experience are less likely to persist in entrepreneurship, those that remain as entrepreneurs will have higher entrepreneurial earnings than individuals with more labor market experience before becoming entrepreneurs.

Tests of these predictions indicated that entrepreneurship generates strongly positive returns for younger workers, particularly ones with higher ability as reflected in their pre-entrepreneurial earnings. Correspondingly, among younger workers the probability of becoming an entrepreneur is greatest among the highest wage earners. To the best of our knowledge, these patterns have not been documented in past studies of self employed, and they are consistent with the Schumpeterian view that returns to entrepreneurship should be especially great among the most talented individuals. We also find that labor market experience increases the probability of entrepreneurship, especially for lower-wage workers, thereby causing the gap between the earnings of entrepreneurs and workers to narrow with age. These patterns are consistent with uncertainty about the value of entrepreneurial ideas inhibiting entrepreneurship, especially among less talented workers. Last, persistence in entrepreneurship is greater for those with more experience at the time of becoming an entrepreneur, but among continuing entrepreneurs earnings are markedly lower for those with more labor market experience before becoming an entrepreneur. For more experienced workers, some of the patterns we find, such as the lowest wage earners being the most likely to become entrepreneurs and negative average returns from entrepreneurship, are not consistent with our theory, and we discuss these exceptions below.

Overall, our theory provides a unified explanation for a wide range of patterns, some of which have been found in previous studies of the self employed and others of which were uncovered in the process of testing predictions of our theory. Other theories may also be able to explain some of the patterns but will be hard pressed to explain all of them, especially the ones involving labor market experience and entry, exit, and earnings from entrepreneurship. For example, it could be argued that older workers are more likely to become entrepreneurs because accumulated experience simply makes them better at evaluating and exploiting entrepreneurial opportunities (Blanchflower and Meyer [1994]). But it is not clear why in that case those with more experience prior to 
becoming an entrepreneur would earn less than those with less pre-entrepreneurship experience, particularly among longer-lived entrepreneurs. Alternatively, older workers may be more likely to become self employed because they have accumulated assets over time and liquidity constraints limit entrepreneurship among younger individuals, especially among those whose potential returns are not very high (Evans and Jovanovic [1989]). However, it is not clear how the liquidity constraint theory alone would explain the greater persistence of self employment for older individuals despite lower returns. Other studies have found that cross sectionally age has less effect on the earnings of entrepreneurs than workers (Rees and Shah [1986], Lazear and Moore [1994]) which has been conjectured to be related to incentive contracting regarding employees (Lazear and Moore [1994]). However, this pattern is readily explained by our theory as a byproduct of younger workers being more uncertain about the value of their entrepreneurial ideas, which leads only the most able individuals to choose self employment when they are young.

Past studies based on broad samples of the self employed typically have found that self-employed individuals earn less on average than comparable workers, that lowerwage workers are most likely to switch to self employment, and that individuals remain self employed despite lower growth in their earnings than those of workers (Evans and Leighton [1989], Hamilton [2000], Moore [2004], Blanchflower and Shafdorth [2007]). One way these patterns have been explained is by appealing to the notion of people valuing being their own boss and thus willing to accept lower earnings from self employment (Hamilton [2000]). Others have conjectured that entrepreneurs pay the price to entertain their "taste for variety" (Åstebro and Thompson [2007]) or are naïve and overly optimistic (De Meza and Southey [1996]).

Clearly, none of these interpretations squares with our overall findings for the "technology-related" self employed. They are also hard to reconcile with our findings concerning pre-entrepreneurship labor market experience. For example, it is not immediately obvious why less able (and/or more experienced) individuals would be willing to pay a higher price for being their own boss than less experienced and/or more 
able individuals. ${ }^{8}$ Empirical findings in these past studies do resonate, however, with some of our findings for older individuals as well as for those in the "non-technologyrelated" sample. Among older and non-technology-related workers, those that become self employed are most likely to come from the lowest wage earners and earn less than comparable workers. So how can we reconcile these patterns with our theory?

One answer that is compatible with our theoretical framework is that for certain individuals self employment is their more rewarding option for defensive rather than positive reasons. In our theory, we abstracted from any frictions in the job market that may make it costly for individuals to find jobs commensurate with their ability. But suppose an individual loses his job or discovers that his job is not as rewarding psychically as anticipated. Then he will need to search for a job commensurate with his ability, which can be costly, and especially so if he is older and not willing to relocate because of having established roots in his community. Even though self employment may not have previously been attractive, if may become attractive if it is sufficiently costly to find a job commensurate with one's ability.

We can take this into account in our model. Suppose a worker with ability $a_{i}$ loses a job commensurate with his ability (i.e., paying $a_{i}$ ). Furthermore, suppose that among the jobs he is willing to consider, the highest wage (net of relocation and other costs) is $a_{i}-k_{i}$, where $0<k_{i}<a_{i}$. Given that he chose to be a worker (prior to losing his job), it must have been the case that either $\hat{\mu}_{i}<1 / a_{i}$ or $\theta_{i}<1 / a_{i}$, where $\hat{\mu}_{i}$ and $\theta_{i}$ are, once again, the expected value and the true value of his entrepreneurial idea, respectively. If $\hat{\mu}_{i}\left(\theta_{i}\right)$ is such that:

$$
\left(1 / a_{i}-k_{i} / a_{i}^{2}\right)<\hat{\mu}_{i}\left(\theta_{i}\right)<1 / a_{i},
$$

then after losing a job entrepreneurship will be the most rewarding option even though the expected returns from entrepreneurship are less than the prior wage. If $k_{i}$ is greater for older workers because, for example, they are less willing to move, then a greater fraction of self-employed individuals at older ages will choose self employment because

\footnotetext{
8 Ohyama [2008] takes up the direct evidence in the SESTAT data about the importance of "being your own boss" for self-employed individuals and concludes that this motivation is more or less uniform across young and old as well as technology-related and non-technology-related self employed.
} 
of defensive reasons. This could account for why the returns to self employment turn negative for older individuals in our sample. Furthermore, suppose that $k_{i}$ is independent of $a_{i}$. Then the range of values of $\hat{\mu}_{i}\left(\theta_{i}\right)$ for which (15) is satisfied will be greater for less able individuals, hence the probability of becoming an entrepreneur after the loss of a job or the desire to move to another job will be greater for lower-wage workers. This could explain in our sample the high rate of becoming self employed among older, lowwage workers and the lower earnings from self employment versus work for such individuals.

We probed this conjecture by re-estimating equations (10) - (12) excluding the lowest paid workers in each age cohort. ${ }^{9}$ The new estimates conform much better with our theory. In equation (10), the estimates of $\beta_{1}$ and $\beta_{3}$ are such that that the probability of becoming self employed rises with the wage for levels of experience up to 40.5 years, which is very close to the maximum labor experience in our sample (43 years). The estimates of $\beta_{2}$ and $\beta_{3}$ are such that the probability of becoming self employed (still) rises with labor market experience for all workers. In equation (12), becoming self employed now increases earnings for older as well as younger workers up to 29 years of labor market experience, which covers most of the individuals in our sample. ${ }^{10}$ These patterns conform with the theory assuming that only those at lower wage levels became self employed for defensive purposes.

We do not claim that everything in our empirical results lines up perfectly with the Schumpeterian view of entrepreneurship. But the more we focus on people with better human capital who make use of their education and training in their jobs, the more the results suggest that the Schumpeterian entrepreneur is alive and well, just hidden in the sea of self employed, many of whom may have chosen self employment for defensive reasons. Technology-related self employed may be a minority of all self employed, but

\footnotetext{
${ }^{9}$ More specifically, we eliminated from the sample of workers used to estimate equations (10) - (12) those whose earnings in period $t$ were in the bottom quartile for each of the following age cohorts: less than 30 years, 30-34 years, 35-39 years, 40-44 years, $45-49$ years, 50-54 years, 55-59 years, and 60-65 years.
} 
this is the group we are really interested in when looking for the next Bob Noyces and Gordon Moores, as it will typically be these individuals who create great value. Our findings suggest that data on self employment can be useful in understanding entrepreneurship, after all, but we need to be able to find empirical strategies that enable us to sort out the entrepreneurial chaff from the wheat.

${ }^{10}$ We also estimated equation (12) dropping individuals in the lowest earning quartiles in both periods $t$ and $t+1$. In this specification, average earnings of new entrepreneurs are higher than average earnings of workers for all relevant levels of labor market experience. 


\section{References}

Åstebro, Thomas, and Peter Thompson, 2007. "Does it pay to be a jack of all trades?" Mimeo, University of Toronto.

Becker, Gary S. and Kevin M. Murphy, 1992. "The Division of Labor, Coordination Costs, and Knowledge." Quarterly Journal of Economics, 107 (4), 1137-1160.

Bhidé, Amar V. The Origin and Evolution of New Business. Oxford University Press, 2000.

Blanchflower, David G., and Chris Shadford, 2007. "Entrepreneurship in the UK," Foundations and Trends in Entrepreneurship, 3 (4), 257-364.

Blanchflower, David G., and Bruce D. Meyer, 1994. "A Longitudinal Analysis of the Young Self-Employed in Australia and the United States," Small Business Economics, 6 (1), 1-19.

Braguinsky Serguey, and Atsushi Ohyama, 2007. "Where does entrepreneurship pay? Returns to Ability in Technology-Oriented vs. Non-Technology Oriented Businesses.” Working paper, SUNY Buffalo.

Cassiman, Bruno, and Masako Ueda, 2006. "Optimal Project Rejection and New Firm Start-ups." Management Science, 52 (2), 262-275.

Chernoff, Herman, 1968. "Optimal Stochastic Control." Sankhya, The Indian Journal of Statistics, Series A, 30 (3), 221-252.

De Meza, David, and Clive Southey, 1996. “The Borrower's Curse: Optimism, Finance and Entrepreneurship," Economic Journal, Vol. 106, No. 435, 375-386.

Elfenbein, Daniel, Bart Hamilton, and Todd Zenger, 2008. "The Entrepreneurial Spawning of Scientists and Engineers: Stars, Slugs, and the Small Firm Effect.” Working Paper, Washington University, St. Louis.

Evans, David S., and Boyan Jovanovic, 1989. "An Estimated Model of Entrepreneurial Choice Under Liquidity Constraints.” Journal of Political Economy, 97 (4), 808827.

Evans, David S., and Linda S. Leighton, 1989. "Some Empirical Aspects of Entrepreneurship." American Economic Review, May, 519-535. 
Hamilton, Barton H., 2000. "Does Entrepreneurship Pay? An Empirical Analysis of the Returns to Self-Employment." Journal of Political Economy, 108 (3), 604-631.

Hellman, Thomas F., 2007. "When Do Employees Become Entrepreneurs?" Management Science, 53 (6), 919-933.

Klepper Steven, and Peter Thompson, 2008. "Who Founds the Best Firms and Why? Intra-industry Spinoffs and Disagreements.” Working Paper, Carnegie Mellon University.

Lazear, Edward P. and Robert Moore, 1984. "Incentives, Productivity, and Labor Contracts," Quarterly Journal of Economics, 99 (2), 275-296.

Lucas, Rober E., Jr., 1978. "On the Size Distribution of Business Firms," Bell Journal of Economics, 9 (2), 508-523.

Moore, Kevin, 2004. "Comparing the Earnings of Employees and the Self-Employed." Board of Governors of the Federal Reserve.

Ohyama, Atsushi, 2008. "Entrepreneurship and Advanced Technical Knowledge." Working paper, University of Illinois.

Rees, Hedley, and Anup Shah, 1986. "An Empirical Analysis of Self-Employment in the U.K." Journal of Applied Econometrics, 1 (1), 95-108.

Schumpeter, Joseph A., 1949. Theory of Economic Development. Harvard University Press, Cambridge, Massachusetts.

Shane, Scott A., 2003. A General Theory of Entrepreneurship: The IndividualOpportunity Nexus. Edward Elgar Publishing, Cheltenham, U.K.

Shane, Scott and S. Venkataraman, 2000. "The Promise of Entrepreneurship as a Field of Research.” The Academy of Management Review, 25 (1), 217-226. 


\section{Appendix: Proofs}

\section{Proof of Proposition 3.}

From Proposition 2 in the main text, we have $\omega_{a 3}>\omega_{a 2}$ for each level of ability $a$, so that $\Omega_{3}>\Omega_{2}$. Consider first the limiting behavior of the function $Z(a)$ in the main text. As $a \rightarrow 0$ we have

$$
\begin{aligned}
& Z(a)=\frac{\omega_{a 2}}{\Omega_{2}}-\frac{\omega_{a 3}}{\Omega_{3}} \leq \frac{\omega_{a 2}}{\Omega_{2}}-\frac{\omega_{a 3}}{\Omega_{2}}=\frac{1}{\Omega_{2}}\left(\omega_{a 2}-\omega_{a 3}\right)= \\
& \frac{1}{\Omega_{2}}\left(\Phi\left(1 / a \sigma_{\theta}\right)-\Phi(1 / a S)\right)=-\frac{1}{\Omega_{2} \sqrt{2 \pi}} \int_{1 / a \sigma_{\theta}}^{1 / a S} e^{-\frac{x^{2}}{2}} d x,
\end{aligned},
$$

and, similarly,

$$
Z(a) \geq \frac{\omega_{a 1}}{\Omega_{3}}-\frac{\omega_{a 2}}{\Omega_{3}}=-\frac{1}{\Omega_{3} \sqrt{2 \pi}} \int_{1 / a \sigma_{\theta}}^{1 / a S} e^{-\frac{x^{2}}{2}} d x .
$$

Taking limits, we have:

$$
\begin{aligned}
& \lim _{a \rightarrow 0} Z(a) \leq-\frac{1}{\Omega_{2} \sqrt{2 \pi}} \lim _{a \rightarrow 0}\left(\int_{1 / a \sigma_{\theta}}^{1 / a S} e^{-\frac{x^{2}}{2}} d x\right)=0 \text { and } \lim _{a \rightarrow 0} Z(a) \geq-\frac{1}{\Omega_{3} \sqrt{2 \pi}} \lim _{a \rightarrow 0}\left(\int_{1 / a \sigma_{\theta}}^{1 / a S} e^{-\frac{x^{2}}{2}} d x\right)=0, \text { or } \\
& 0 \leq \lim _{a \rightarrow 0} Z(a) \leq 0 \Rightarrow \lim _{a \rightarrow 0} Z(a)=0 .
\end{aligned}
$$

On the other hand, as $a \rightarrow \infty$, we have $\lim _{a \rightarrow \infty} Z(a)=\frac{1}{2 \Omega_{2}}-\frac{1}{2 \Omega_{3}}>0$. Also, differentiating $Z(a)$ we obtain

$$
Z^{\prime}(a)=\frac{e^{-\frac{1}{2 a^{2} S^{2}}}}{a^{2} \sqrt{2 \pi} S \Omega_{2}}-\frac{e^{-\frac{1}{2 a^{2} \sigma_{\theta}^{2}}}}{a^{2} \sqrt{2 \pi} \sigma_{\theta} \Omega_{3}}=\frac{e^{-\frac{1}{2 a^{2} S^{2}}}}{a^{2} \sqrt{2 \pi} S \Omega_{2}}\left(1-\alpha e^{\frac{\lambda}{a^{2}}}\right),
$$

where $\alpha \equiv \frac{\Omega_{2} S}{\Omega_{3} \sigma_{\theta}}<1$ and $\lambda \equiv \frac{\sigma_{\theta}^{2}-S^{2}}{2 \sigma_{\theta}^{2} S^{2}}>0$. Obviously, $Z^{\prime}(a)$ is a continuous function and its sign is determined by the sign of the last expression in brackets in (A1). Let $\widetilde{a}$ be the value of $a$ for which this expression is equal to zero, that is, $\widetilde{a}=\sqrt{\lambda / \ln (1 / \alpha)}$. Obviously, $0<\widetilde{a}<\infty, Z^{\prime}(a)<0, \forall a<\widetilde{a}$ and $Z^{\prime}(a) \geq 0, \forall a \geq \widetilde{a}$. Therefore, starting from zero $Z(a)$ initially declines and becomes negative and then starts increasing past $\widetilde{a}$ and eventually must exceed zero (at some finite $a=\hat{a}$ ) since the limit of $\mathrm{Z}(a)$ as $a$ approaches infinity is positive. The behavior of $Z(a)$ is illustrated in Figure 1 .

[Insert Figure A1 here]

\section{Proof of Proposition 7.}

The average earnings of entrepreneurs with ability level $a$ who became entrepreneurs in period 3 is given by 


$$
\bar{E}_{3}(a)=\frac{a^{2}\left[\int_{1 / a}^{\infty} \theta \phi\left(\theta / \sigma_{\theta}\right) d \theta\right]}{\int_{1 / a}^{\infty} \phi\left(\theta / \sigma_{\theta}\right) d \theta}
$$

Consider now entrepreneurs with ability level $a$ who became entrepreneurs in period 2 and stayed entrepreneurs in period 3 . In period 2 , the entry condition was $\hat{\mu} \geq 1 / a$, where $\hat{\mu}$ is given by:

$$
\hat{\mu}=\lambda(\theta+w),
$$

and $\lambda=\sigma_{\theta}^{2} /\left(\sigma_{\theta}^{2}+\sigma_{w}^{2}\right)<1, w \sim N\left(0, \sigma_{w}^{2}\right)$. Hence, conditional on a particular (true) quality of business $\theta$ and ability level $a$ the probability of $\hat{\mu} \geq 1 / a$ is given by:

$$
\kappa(a, \theta)=\operatorname{Pr}\left(\hat{\mu}>\frac{1}{a} \mid a, \theta\right)=1-\Phi\left(\frac{1}{\sigma_{w}}\left(\frac{1}{a \lambda}-\theta\right)\right) .
$$

The expression in (A4) gives the fraction of individuals for given $a$ and $\theta$ who become entrepreneurs in period 2. In period 3, only those whose true business quality satisifies $\theta \geq 1 / a$ stay in entrepreneurship, so that for a given $a$, the mass of long-term survivors is given by

$$
\int_{1 / a}^{\infty} \kappa(a, \theta) \phi\left(\theta / \sigma_{\theta}\right) d \theta
$$

while their average earnings are

$$
\bar{E}_{2 S}(a)=\frac{a^{2} \int_{1 / a}^{\infty} \kappa(a, \theta) \theta \phi\left(\theta / \sigma_{\theta}\right) d \theta}{\int_{1 / a}^{\infty} \kappa(a, \theta) \phi\left(\theta / \sigma_{\theta}\right) d \theta} .
$$

We now show that $\bar{E}_{2 S}(a)-\bar{E}_{3}(a)>0$ for all $a$. Define

$$
\bar{\kappa}(a) \equiv \frac{\int_{1 / a}^{\infty} \kappa(a, \theta) \phi\left(\theta / \sigma_{\theta}\right) d \theta}{\int_{1 / a}^{\infty} \phi\left(\theta / \sigma_{\theta}\right) d \theta} .
$$

Clearly, $0<\bar{\kappa}(a)<1$. Note also that $\kappa(a, \theta)$ is an increasing function of $\theta$ for all $a$, so that, in particular, $\bar{\kappa}(a)>\kappa(a, 1 / a)$, while $\lim _{\theta \rightarrow \infty} \kappa(a, \theta)=1$. Therefore, for each $a$, there exists $\bar{\theta}(a) \in(1 / a, \infty)$ such that $\bar{\kappa}(a)=\kappa(a, \bar{\theta}(a))$ and such that

$$
\kappa(a, \theta)>\kappa(a, \bar{\theta}(a)), \forall \theta>\bar{\theta}(a) ; \kappa(a, \theta)<\kappa(a, \bar{\theta}(a)), \forall \theta<\bar{\theta}(a) .
$$

Write $\bar{E}_{3}(a)=\frac{\bar{\kappa}(a) a^{2}\left[\int_{1 / a}^{\infty} \theta \phi\left(\theta / \sigma_{\theta}\right) d \theta\right]}{\bar{\kappa}(a) \int_{1 / a}^{\infty} \phi\left(\theta / \sigma_{\theta}\right) d \theta}=\frac{a^{2} \bar{\kappa}(a)\left[\int_{1 / a}^{\infty} \theta \phi\left(\theta / \sigma_{\theta}\right) d \theta\right]}{\int_{1 / a}^{\infty} \kappa(a, \theta) \phi\left(\theta / \sigma_{\theta}\right) d \theta}$. Then we have 


$$
\begin{aligned}
& \bar{E}_{2 S}(a)-\bar{E}_{3}(a)=\frac{a^{2}\left[\int_{1 / a}^{\infty}[\kappa(a, \theta)-\bar{\kappa}(a)] \theta \phi\left(\theta / \sigma_{\theta}\right) d \theta\right]}{\int_{1 / a}^{\infty} \kappa(a, \theta) \phi\left(\theta / \sigma_{\theta}\right) d \theta} \\
& =\frac{a^{2}\left[\int_{1 / a}^{\bar{\theta}(a)}[\kappa(a, \theta)-\bar{\kappa}(a)] \theta \phi\left(\theta / \sigma_{\theta}\right) d \theta\right]}{\int_{1 / a}^{\infty} \kappa(a, \theta) \phi\left(\theta / \sigma_{\theta}\right) d \theta}+\frac{a^{2}\left[\int_{\bar{\theta}(a)}^{\infty}[\kappa(a, \theta)-\bar{\kappa}(a)] \theta \phi\left(\theta / \sigma_{\theta}\right) d \theta\right]}{\int_{1 / a}^{\infty} \kappa(a, \theta) \phi\left(\theta / \sigma_{\theta}\right) d \theta}> \\
& \frac{a^{2} \bar{\theta}(a)\left[\int_{1 / a}^{\bar{\theta}(a)}[\kappa(a, \theta)-\bar{\kappa}(a)] \phi\left(\theta / \sigma_{\theta}\right) d \theta\right]}{\int_{1 / a}^{\infty} \kappa(a, \theta) \phi\left(\theta / \sigma_{\theta}\right) d \theta}+\frac{a^{2} \bar{\theta}(a)\left[\int_{\bar{\theta}(a)}^{\infty}[\kappa(a, \theta)-\bar{\kappa}(a)] \phi\left(\theta / \sigma_{\theta}\right) d \theta\right]}{\int_{1 / a}^{\infty} \kappa(a, \theta) \phi\left(\theta / \sigma_{\theta}\right) d \theta}= \\
& a^{2} \bar{\theta}(a)\left[\frac{\int_{1 / a}^{\infty} \kappa(a, \theta) \phi\left(\theta / \sigma_{\theta}\right) d \theta}{\int_{1 / a}^{\infty} \kappa(a, \theta) \phi\left(\theta / \sigma_{\theta}\right) d \theta}-\frac{\bar{\kappa}(a) \int_{1 / a}^{\infty} \phi\left(\theta / \sigma_{\theta}\right) d \theta}{\int_{1 / a}^{\infty} \kappa(a, \theta) \phi\left(\theta / \sigma_{\theta}\right) d \theta}\right]=0
\end{aligned}
$$

where the inequality between the second and third lines follows from (A8) (because we are replacing all negative terms in the first integral by their upper bound and all positive terms in the second integral by their lower bound) and the last equality follows from the definition of $\bar{\kappa}(a)$ in (A7). Thus, $\bar{E}_{2 S}(a)-\bar{E}_{3}(a)>0, \forall a$. 
Figure A1.

The behavior of the $Z(a)$ function in Proposition 3 .

$Z(a), Z^{\prime}(a)$

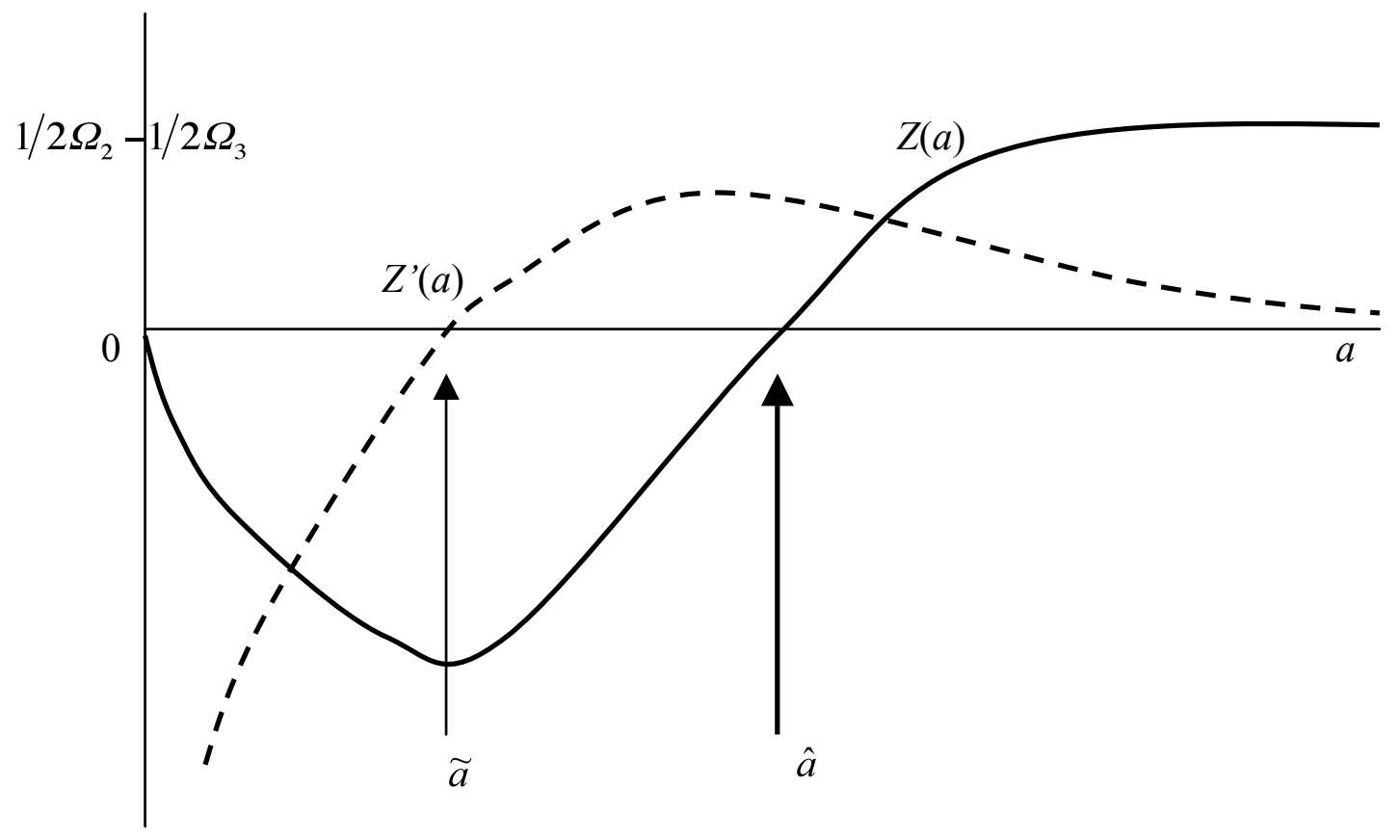


Table A.1 List of Occupations

\begin{tabular}{|c|}
\hline occupation 1 \\
\hline Computer Systems Analysts \\
\hline Computer Scientists, Except Systems Analysts \\
\hline Information Systems Scientists and Analysts \\
\hline OTHER Computer and Information Science Occupations \\
\hline occupation 2 \\
\hline Computer Engineers-Software \\
\hline occupation 3 \\
\hline Biochemists and Biophysicists \\
\hline Biological scientists \\
\hline Medical Scientists, Except Practitioners \\
\hline occupation 4 \\
\hline Agricultural and Food Scientists \\
\hline OTHER Biological and Life Scientists \\
\hline Forestry and Conservation Scientists \\
\hline occupation 5 \\
\hline Chemists, except Biochemists \\
\hline occupation 6 \\
\hline Astronomer \\
\hline Physicists \\
\hline occupation 7 \\
\hline Atmospheric and Space Scientists \\
\hline Geologists \\
\hline Oceanographers \\
\hline OTHER Physical and Related Scientists \\
\hline occupation 8 \\
\hline Economists \\
\hline occupation 9 \\
\hline Psychologists \\
\hline occupation 10 \\
\hline Political Scientists \\
\hline Anthropologists, Sociologists \\
\hline Historians, Science and Technology, Other Social Scientists \\
\hline occupation 11 \\
\hline Environmental Engineers \\
\hline occupation 12 \\
\hline Chemical Engineers \\
\hline occupation 13 \\
\hline Civil Engineers \\
\hline occupation 14 \\
\hline Electrical and Electronics Engineers \\
\hline occupation 15 \\
\hline Mechanical Engineers \\
\hline
\end{tabular}

\begin{tabular}{|c|}
\hline occupation 16 \\
\hline Top and Mid-Level Managers, Executives, Administrators \\
\hline occupation 17 \\
\hline Accountants, Auditors, and other Financial Specialists \\
\hline occupation 18 \\
\hline Personnel, Training and Labor Relations Specialists \\
\hline occupation 19 \\
\hline OTHER Management Related Occupations \\
\hline occupation 20 \\
\hline Counselors, Educational and Vocational \\
\hline Social Workers \\
\hline occupation 21 \\
\hline Computer Programmers \\
\hline occupation 22 \\
\hline Sales/Mrkt. - Insurance, Securities, Real Est. \& Bus. Serv. \\
\hline occupation 23 \\
\hline Sales Occupations - Commodities, Except Retail \\
\hline occupation 24 \\
\hline Sales Occupations - Retail \\
\hline occupation 25 \\
\hline OTHER Marketing and Sales Occupations \\
\hline occupation 26 \\
\hline Artists, Editors, Entertainers, Public Relations, Writers \\
\hline occupation 27 \\
\hline Accounting Clerks and Bookkeepers \\
\hline Secretaries, Receptionists and Typists \\
\hline OTHER Administrative \\
\hline occupation 28 \\
\hline Architects \\
\hline occupation 29 \\
\hline Food Preparation and Service Workers \\
\hline occupation 30 \\
\hline OTHER Service Occupations, Except Health \\
\hline occupation 31 \\
\hline Construction Trades, Miners and Well-Drillers \\
\hline occupation 32 \\
\hline Mechanics and Repairers \\
\hline occupation 33 \\
\hline Precision Production Occupations \\
\hline occupation 34 \\
\hline Operators and Related Occupations \\
\hline Transportation and material-moving occupations \\
\hline
\end{tabular}

